of physiology and a professor of pathology. The maximum salary for these positions is fixed at $\$ 5,000$.

\section{ARCHEOLOGICAL WORK IN ARIZONA}

During the past season the Committee on American Archeology of the Archeological Institute of America offered properly qualified students the privilege of joining the field expeditions of the Institute in Colorado, Utah and New Mexico. A number of students availed themselves of the opportunity to participate in the practical work of exploration, mapping and excavation of ruins in the San Juan and Rio Grande basins. These expeditions closed on October 1.

Through the courtesy of the Secretary of the Smithsonian Institution the committee is authorized to announce that the government excavations at Casa Grande, in the Gila Valley, Arizona, will be resumed about November 1, under the direction of Dr. J. Walter Fewkes, to continue during the fall and winter, and that students may arrange through the Archeological Institute to participate in the work at this site. As government institutions are not permitted to accept volunteer services, Dr. Fewkes is authorized to pay a limited number of students (not to exceed ten) for their services in connection with the work a nominal salary of ten dollars per month, it being understood that they provide for their own traveling expenses and subsistence. This nominal salary will about cover field subsistence at Casa Grande.

Students desiring to avail themselves of this opportunity should correspond with the undersigned as early as convenient. Applications should be accompanied by the recommendation of the professor under whom the appli-' cant has studied. Edgar L. Hewett, Director of American Archeology

Archeological Institute of America, 1333 F Street, Washington, D. C., October 21, 1907

\section{BRITISH MUSEUM MODEL OF EURYPTERUS}

In the Upper Silurian rocks of the island of Oesel, in the Baltic, are found the fossil remains of an arthropod called Eurypterus
Fischeri. This animal is of interest as one of an extinct group of arthropods that appear to have been allied to the modern Limulus or king-crab, as well as to the scorpions. These particular fossils have a further interest in that the chitinous substance of the outer coat of the animal has been preserved unaltered in chemical and physical composition. Thus Professor G. Holm, of Stockholm, has been able to dissolve the remains out from the rock by means of acid, and to mount them on glass slides in Canada balsam. On the preparations thus obtained, he based an elaborate description, published in the Memoirs of the Academy of Science, St. Petersburg (Ser. 8, Vol. VIII., No. 2, 1898). It can now be said that the structure of this species is known better than that of any other extinct arthropod. Several of Professor Holm's preparations preserved in the geological department of the British Museum are quite marvelous, ano it is difficult to believe that one is looking at a fossil at all, still more one dating from the Silurian Epoch.

The perfection of these specimens and the interest of the animal suggested to members of the staff of the British Museum (Natural History) the advisability of preparing a complete model of it, and such a model in colored wax, of about twice the natural size, has now been made under the direction of Dr. W. T. Calman and Dr. F. A. Bather by Mrs. Vernon Blackman, whose beautiful models of plants, of the parasite of malaria, and of the tsetse fly are well known to all visitors to the Natural History Museum in the Cromwell Road.

The model was first placed on exhibition on the occasion of the visit of foreign geologists to the Centenary of the Geological Society of London and evoked their enthusiastic admiration. It measures $23 \times 15 \mathrm{~cm}$. The wax of which it is made will stand any extremes of temperature likely to be met with in a museum, and the colors are believed to be quite. permanent; they are based upon those of the recent Limulus, and Sir Ray Lankester has shown great interest in their selection. The model which, it may be mentioned, has been subjected to the careful scrutiny of Professor 